
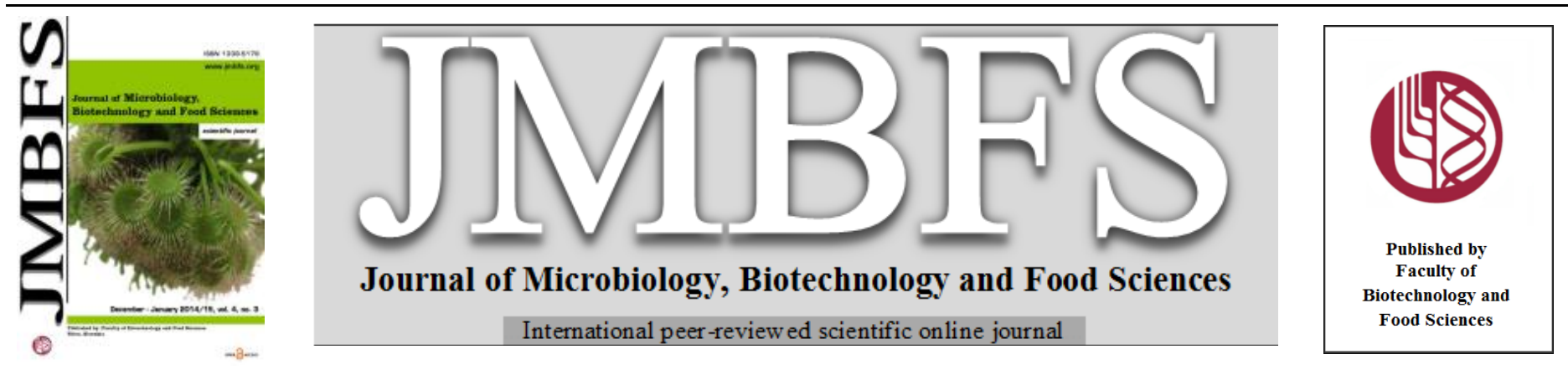

\title{
IDENTIFICATION OF GYMNEMA SPECIES BY RANDOM AMPLIFIED POLYMORPHIC DNA TECHNIQUE AND CHLOROPLAST trnK GENE
}

\author{
Subashini Sekar ${ }^{1}$, Subburaj Jayachandran ${ }^{2}$, Pugalendi Viswanathan Kodukkur ${ }^{* 1}$ \\ Address(es): Pugalendi Viswanathan Kodukkur, \\ ${ }^{1}$ AnnamalaiUniversity, Faculty of Science, Department of Biochemistry and Biotechnology, Annamalai nagar, 608002, Tamilnadu, Phone number: 04144-239141. \\ ${ }^{2}$ Annamalai University, Faculty of Marine Sciences, CAS in Marine Biology, Portonovo, 608502, Tamilnadu, India.
}

*Corresponding author: pugale@ sifymail.com

doi: 10.15414/jmbfs.2014-15.4.3.266-270

\section{ARTICLE INFO}

Received 11. 12. 2013

Revised 30. 9. 2014

Accepted 3. 11. 2014

Published 1. 12. 2014

Short communication

open $\partial_{\text {AcCESS }}$

\begin{abstract}
Gymnema is one of the important anti-diabetic medicinal plants used from ancient times and is commonly known as 'sugar killer'. Most of its species have been used in many applications in Indian traditional medicine. Nevertheless, their efficiency is critically dependent on the use of the correct material. The sharing of similar vernacular name and morphological features make confusion in the usage of Gymnema species. In the present study, Gymnema sp. were identified through random amplified polymorphic DNA (RAPD) technique and species specific markers were generated for easy identification of G. elegans, G. montanum and G. sylvestre. Using the RAPD techniques of 3 species specific markers for G. sylvestre, 7 markers for G. elegans and 4 markers for G. montanum had been generated. Highest genetic identity was found between G. sylvestre and G. montanum and highest genetic distance was found between G. sylvestre and G. elegans. Further, DNA barcode was developed by sequencing chloroplast partial trnK DNA of these three species. No significant variation was found in partial trnK gene sequences between Gymnema species. But these sequences can efficiently differentiate the Gymnema and Mandevilla species. In-silico sequence-restriction fragment length polymorphism (RFLP) analysis revealed three fragments measuring G. sylvestre - 204, G. elegans - 174, and G. montanum - 168 bp Gymnema species. The present study concluded that RAPD markers were highly efficient for species detection than the partial trnK gene sequences. This could be used to confirm the Gymnema sp. identities and to ensure their safe application in pharmaceuticals.
\end{abstract}

Keywords: Gymnema species identification, G. sylvestre, G. elegans,G. montanum, RAPD, trnK sequences, barcode

\section{INTRODUCTION}

Gymnema is an important plant genus in terms of therapeutic applications. Generally, it is referred to as sugar killer due to its anti-diabetic potential. Most of its species has been used in traditional Indian medicine for curing the disease such as diabetes, stomach ailments, constipation, water retention, and liver disease (Chattopadhyay, 1998). There are more than 40 species in Gymnema and some of them are uncategorized because of sharing of similar morphological features among the species. In that, three species of Gymnema namely, $G$ sylvestre, G. elegans and G. montanum have shared similar morphological traits with different medicinal properties. Notably, G. elegans are used as an alternate for G. sylvestre in traditional medicine for the treatment of diabetes (Rana et al., 1994) and snake bite (Masilamani, 1995). It also possesses the antimicrobial properties. G. montanum is also used traditionally to treat disorders such as diabetes, high cholesterol, wounds, inflammation, and gastrointestinal ailments. Some authors have reported that extracts of some Gymnema species ( $G$. sylvestre, G. inodorum, and G. yunnanense) involved in the repair mechanism or regenerate pancreatic $\beta$-cells (Persaud et al., 1999; Shimizu et al., 2001; Xie et al., 2003).Likewise several Gymnema species shared many medicinal properties. Nevertheless, their efficiency is critically dependent on the use of the correct material. Misidentification of medicinal plants leads to severe health problems in several countries. In 2002, 63 people were reported with symptoms of general malaise, nausea and vomiting after consumption of herbal tea which was inadvertently mixed with neurotoxic Japanese star anise (Illiciumanisatum) (Johanns et al., 2002). Adulteration resulting in an epidemic of severe kidney damages caused by aristolochic acid was first reported in Belgium in 1993 (Vanherweghem et al., 1993), followed by Hong Kong and Korea (Lo et al., 2004; Lee et al., 2004). In these cases, the concerned herbs were substituted with the nephrotoxic Aristolochia species. A case of misusing Daturametel as Rhododendron molle was reported in Singapore in 2008 (Phua et al., 2008). These two species share the same Chinese herb name "Naoyanghua", but $D$. metel contains anti-cholinergic compound that causes confusion, dilated pupils and absence of sweating. Therefore, correct identification of medicinal plants is very important to use in therapeutic applications. Recent advancement in the molecular techniques provides several ways to examine the species. Molecular markers give information that helps in deciding the distinctiveness of species and their ranking according to the number of close relatives and phylogenetic position (Thomas et al., 2006). Here we have applied random amplified polymorphic DNA technique and trnK gene sequences to generate species specific profile for three important medicinal plants namely $G$. sylvestre, $G$. elegans, and $G$. montanum.

\section{MATERIAL AND METHODS}

\section{Plant material}

Three species of Gymnema viz. G. sylvestre, G. montanum and G. elegans (Supplementary) were collected in the month of September from the garden of Department of Horticulture, Faculty of Agriculture, Annamalai University, Tamilnadu, India and were identified by the Taxonomist in the Department of Botany, Annamalai University. Fresh leaves were collected and kept at $-80{ }^{\circ} \mathrm{C}$ for further analysis.

\section{Genomic DNA extraction}

Total genomic DNA was extracted from $100 \mathrm{mg}$ of leaves using a modified protocol of CTAB (Cetyl tri-methyl ammonium bromide) (Doyle, 1991). A 50 $\mu \mathrm{L}$ of DNA solution was purified using ExoSAP-IT ${ }^{\mathbb{B}}$ (Affymetrix, Santa Clara, CA). The quality of purified DNA was checked using 0.8\% agarose gel electrophoresis, stained with ethidium bromide and visualized under UV light. The quantity of DNA concentration was determined using UV spectrophotometer (Shimadzhu, Japan) by taking the optical density at $260 \mathrm{~nm} / 280 \mathrm{~nm}$. Final concentration of DNA was adjusted to $50 \mathrm{ng} / \mu \mathrm{L}$ using double distilled water. The DNA samples were stored at $-20^{\circ} \mathrm{C}$ until further use. 


\section{RAPD analysis}

Totally 10 plants RAPD primers were used for random amplification and their sequences are given in Tab 1 . A total volume of $25 \mu \mathrm{L}$ PCR recipe consisting 18 $\mu \mathrm{L}$ of dd. $\mathrm{H}_{2} \mathrm{O}, 2.5 \mu \mathrm{L}$ of $10 \mathrm{X}$ buffer with $15 \mathrm{mM} \mathrm{MgCl}_{2}, 2 \mu \mathrm{L}$ of dNTP $(2.5 \mathrm{mM}$ each), $0.5 \mu \mathrm{L}$ of Taq DNA polymerase $(3 \mathrm{U} / \mu \mathrm{L})$, one $\mu \mathrm{L}$ of RAPD primer (10 $\mathrm{pmol} / \mu \mathrm{L})$ and one $\mu \mathrm{L}$ of genomic DNA $(1 \mathrm{ng} / \mu \mathrm{L})$ was prepared out for RAPD analysis. The whole mixture was placed on a thermal cycler (TECHNE, Genei) programmed for $5 \mathrm{~min}$ at $95{ }^{\circ} \mathrm{C}$ followed by 40 cycles for $60 \mathrm{~s}$ at $95{ }^{\circ} \mathrm{C}, 45 \mathrm{~s}$ at $35{ }^{\circ} \mathrm{C}$ and $90 \mathrm{~s}$ at $72{ }^{\circ} \mathrm{C}$, and finally one cycle at $72{ }^{\circ} \mathrm{C}$ for $10 \mathrm{~min}$. The amplification products were resolved with $1.5 \%$ agarose gel stained with electrophoresis at $150 \mathrm{~V}$ and $140 \mathrm{~mA}$ using $1 \mathrm{X}$ TAE (Tris acetate with EDTA) for $3 \mathrm{~h}$ ethidium bromide. A $100 \mathrm{bp}$ ladder was used as a molecular mass marker. The RAPD patterns were visualized in a gel documentation system (Alphaview software). For reproducibility, the concentration and the protocol was strictly followed and repeating the amplification process twice in order to score clear reproducible bands for all the ten RAPD primers. Species specific monomorphic and polymorphic bands were identified.

Table 1 Primers used for the identification of three Gymnema species RAPD techniques

\begin{tabular}{lc}
\hline Name of the Primers & Sequences of the Primers \\
\hline RP1 & $5^{\prime}$-CAATCGCCGT - 3' \\
RP 2 & $5^{\prime}$-CAGAACCCAC - 3' \\
RP 3 & $5^{\prime}$ - CTCGTGCTGG - 3' \\
RP 4 & $5^{\prime}-$ TTCCGAACCC - 3' \\
RP 5 & $5^{\prime}$ - GACCGCTTGT - 3' \\
RP 6 & $5^{\prime}$ - AGGTGACCGT - 3' \\
RP 7 & $5^{\prime}$ - TCCAACGGCT - 3' \\
RP 8 & $5^{\prime}$ - CAGTGGGGAG - 3' \\
RP 9 & $5^{\prime}$ - TGCGGCTGAG - 3' \\
RP 10 & $5^{\prime}$ - ACGCACAACC - 3' \\
\hline
\end{tabular}

\section{PCR amplification of the trnK region}

The sequences of trnK gene primers are given in Table 2. The PCR amplification of trnK region was performed in a $25 \mu \mathrm{L}$ PCR recipe consisting $18 \mu \mathrm{L}$ of dd. $\mathrm{H}_{2} \mathrm{O}$, $2.5 \mu \mathrm{L}$ of $10 \mathrm{X}$ buffer with $15 \mathrm{mM} \mathrm{MgCl} 2,2 \mu \mathrm{L}$ of dNTP $(2.5 \mathrm{mM}$ each $), 0.5 \mu \mathrm{L}$ of Taq DNA polymerase $(3 \mathrm{U} / \mu \mathrm{L}), 1 \mu \mathrm{L}$ of trnK primer $(10 \mathrm{pmol} / \mu \mathrm{L})$ and $1 \mu \mathrm{L}$ of genomic DNA $(1 \mathrm{ng} / \mu \mathrm{L})$. The whole mixture was placed on a thermal cycler (TECHNE, Genei) programmed for $5 \mathrm{~min}$ at $95{ }^{\circ} \mathrm{C}$ followed by 35 cycles for $30 \mathrm{~s}$ at $95{ }^{\circ} \mathrm{C}, 1 \mathrm{~min}$ at $49^{\circ} \mathrm{C}$ and $2 \mathrm{~min}$ at $68^{\circ} \mathrm{C}$, and finally one cycle at $68{ }^{\circ} \mathrm{C}$ for 10 min. The amplified products were checked with $1.5 \%$ agarose gel and stained with electrophoresis at $150 \mathrm{~V}$ and $140 \mathrm{~mA}$ using $1 \mathrm{X}$ TAE (Tris acetate with EDTA) for $1 / 2 \mathrm{~h}$ and ethidium bromide. The size of the amplified product was calculated using a $100 \mathrm{bp}$ molecular ladder.

Table 2 Primers used in trnK gene

Name of the primers Sequences of the primers

$$
\operatorname{trnK}-\mathrm{F}
$$

$$
\text { 5'- GGGTTGCTAACTCAATGGTAGAG - 3' }
$$

$\operatorname{trnK}-\mathrm{R}$

$$
\text { 5'- TGGGTTGCCCGGGGCTCGAAC - 3' }
$$

$\mathrm{F}-$ forward, $\mathrm{R}$ - reverse

\section{Sequencing and phylogenetic analyses}

The purified PCR products were sent to Macrogen, Inc. (Seoul, Korea) for unidirectional sequencing. The DNA sequence analyzer 3730xl DNA analyzer with Big Dye Terminator Cycle Sequencing Kit V3.1 (Applied Biosystems) was used for sequencing. The electropheretogram was analysed using BioEdit sequence alignment editor. Sequences with good peak clarities were selected for further analyses. The edited sequences were aligned in ClustalW program. The edited sequences were identified using BLAST program of NCBI nucleotide database. Based on the similarity index, the amplified products were assigned as trnK sequences and were recorded in the NCBI's nucleotide database with accession number JX569772, JX569773 and JX569774. Phylogenetic relationship was constructed using Neighbor-Joining statistical method. Uniform rates were followed among the sequences. Bootstrapping was performed with 1000 replications. Kimura two parameter (Kimura, 1980) model of evolution was followed in the analyses. All positions containing gaps and missing data were eliminated. Mandevilla venulosa and M. Duartei were used as an out group.

\section{trnK - RFLP analysis}

Restriction map of the five sequences (3 Gymnema species and 2 Mandevilla species) were generated. These sequences were online digested with TaqI restriction enzyme in the NEB cutter tools (New England BioLabs). Restriction map was shown in $1.4 \%$ agarose gel with $100 \mathrm{bp}$ molecular ladder and the fragment sizes were calculated.

\section{Statistical analysis}

Genetic similarity/distance between the three species was estimated using PopGen Software (Version 1.31, (Yeh et al., 1999). Nei and Li's (1979) genetic similarity (GS) among the three species was computed and converted by PopGen into genetic distance (GD) according to Hillis and Mortiz's (1990). Formula, GD $=1-$ GS. The GS reflects the proportion of the bands shared between individuals and values range from (1) when present to (0) when absent. Phylogenetic relationship was estimated based on genetic distance values generated from RAPD data among three species. A dendrogram was plotted based on Nei (1978) method using PHYLIP version 3.2 (Felsenstein, 1993).

\section{RESULTS}

\section{RAPD bands}

Figure 1 shows the RAPD profiles of all three species for 10 RAPD primers. All the 10 RAPD primers selected were successfully amplified and gave good RAPD profiles for the three species of Gymnema. Totally 427 scorable bands were observed in three species for each in the three replicates of Gymnema, ranging in size from 1412 to $218 \mathrm{bp}$. As observed in Tab 3, RAPD analysis revealed species specific markers like three markers viz., 787 bp by RP6, 354 bp by RP7 and 744 bp by RP10 for G. sylvestre, seven markers viz. 510 bp by RP3, 1078 bp, 962 bp by RP4, 825 bp by RP5, 1018 bp by RP6, 671 bp by RP7 and 378 bp by RP9 for G. elegans and four markers 815 bp by RP2, 923 bp by RP7, 1150 bp, 579 bp by RP8 for $G$. montanum. These species specific markers generated by these RAPD primers could be used to identify and differentiate the species of Gymnema unambiguously. Especially, RP7 primer could be used efficiently to discriminate the Gymnema species by producing species specific markers 354 bp in $G$ sylvestre, $671 \mathrm{bp}$ in G. elegans and $923 \mathrm{bp}$ in G. montanum and in addition these bands can be clearly figured out in the agarose gel electrophoresis. Much difference was not observed in the frequencies of polymorphic bands between the three species. The polymorphic percentage of $G$. sylvestre, G. elegans, and $G$. montanum were predicted as $38.32 \%, 39.56 \%$, and $40.81 \%$, respectively.
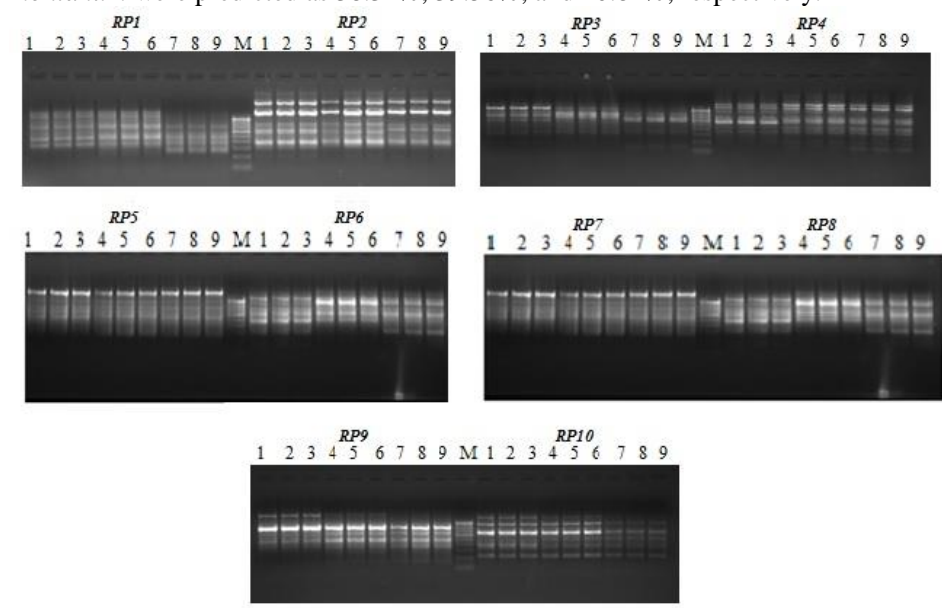

Figure 1 RAPD banding pattern of Gymnema species using the primers $R P 1$ to RP10 (Lanes: 1-3 G. sylvestre; 4-6 G. elegans; 7-9 G. montanum. M - 100 bp marker ladder) 
Table 3 Number of monomorphic and polymorphic bands in three species of Gymnema by RAPD

\begin{tabular}{|c|c|c|c|c|c|c|c|c|c|}
\hline \multirow[b]{2}{*}{$\begin{array}{l}\text { Name of } \\
\text { the } \\
\text { primer }\end{array}$} & \multicolumn{3}{|c|}{ Gymnema sylvestre } & \multicolumn{3}{|c|}{ Gymnema elegans } & \multicolumn{3}{|c|}{ Gymnema montanum } \\
\hline & $\begin{array}{l}\text { RAPD band } \\
\text { range (bp) }\end{array}$ & $\begin{array}{c}\text { No.of } \\
\text { monomorp } \\
\text { hic bands } \\
\text { (size) }\end{array}$ & $\begin{array}{l}\text { No.of } \\
\text { polymorphic } \\
\text { bands }\end{array}$ & $\begin{array}{l}\text { RAPD band } \\
\text { range (bp) }\end{array}$ & $\begin{array}{l}\text { No.of monomorphic } \\
\text { bands /size (bp) }\end{array}$ & $\begin{array}{l}\text { No.of } \\
\text { polymorphi } \\
\text { c bands }\end{array}$ & $\begin{array}{l}\text { RAPD } \\
\text { band range } \\
\text { (bp) }\end{array}$ & $\begin{array}{c}\text { No.of } \\
\text { monomorphic } \\
\text { bands /size }\end{array}$ & $\begin{array}{c}\text { No.of } \\
\text { polymorphic } \\
\text { bands }\end{array}$ \\
\hline$R P 1$ & $1355-480$ & - & 18 & $1327-610$ & - & 18 & $1418-780$ & - & 22 \\
\hline$R P 2$ & $1136-150$ & - & 14 & $1136-290$ & - & 17 & $815-420$ & $1(815)$ & 10 \\
\hline$R P 3$ & $1320-250$ & - & 16 & $1320-218$ & $1(510)$ & 14 & $1320-218$ & - & 20 \\
\hline RP6 & $1155-253$ & $1(787)$ & 12 & $1155-251$ & 1(1018) & 14 & $1155-305$ & - & 9 \\
\hline$R P 7$ & $993-260$ & $1(354)$ & 15 & $1091-245$ & $1(671)$ & 14 & 923-258 & $1(923)$ & 9 \\
\hline$R P 8$ & $1090-310$ & - & 12 & $1110-265$ & - & 18 & $1150-270$ & $2(1150,579)$ & 16 \\
\hline$R P 9$ & $1145-365$ & - & 18 & $1127-363$ & $1(378)$ & 13 & $1164-363$ & - & 8 \\
\hline RP10 & $1150-338$ & $1(744)$ & 14 & $1158-320$ & - & 12 & 938-384 & - & 13 \\
\hline
\end{tabular}

The genetic identity and genetic distance between the species of Gymnema is given in Tab 4. The genetic identity (above diagonal) ranged from 0.8968 to 0.9153 and inter-species distance ranged from 0.0885 to 0.1089 based on Nei's band sharing frequencies. High genetic identity was found between $G$. sylvestre and $G$. montanum and highest genetic distance was found between $G$. sylvestre and G. elegans.

Table 4 Nei's genetic identity (above diagonal) and genetic distance (below diagonal) of Gymnema species.

\begin{tabular}{lccc}
\hline Species & G. sylvestre & G. montanum & G. elegans \\
\hline G. sylvestre & $* * * *$ & 0.9153 & 0.8968 \\
G. montanum & 0.0885 & $* * * *$ & 0.9035 \\
G. elegans & 0.1089 & 0.1014 & $* * * *$ \\
\hline
\end{tabular}

Based on genetic distances, dendrogram was generated by UPGMA method which showed the relationship between the Gymnema species. Figure 2 depicts the dendrogram of Gymnema with bootstrap support value. G. sylvestre and $G$ montanum exhibits close relationship while $G$. elegans occurred as a single main clade.
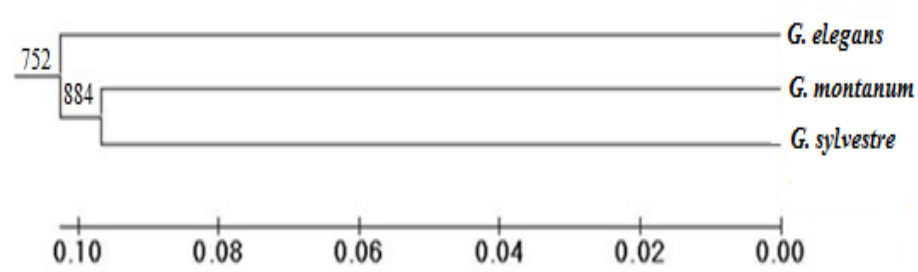

Figure 2 UPGMA dendrogram using Nei's genetic distances inferred from RAPD (Bootstrap values based on 1000 replications given in the nodes)

$\operatorname{trnK}$

trnK-F and trnK-R primers were successfully amplified using Gymnema species and the amplified products were predicted to have $700 \mathrm{bp}$ in length (Figure 3).

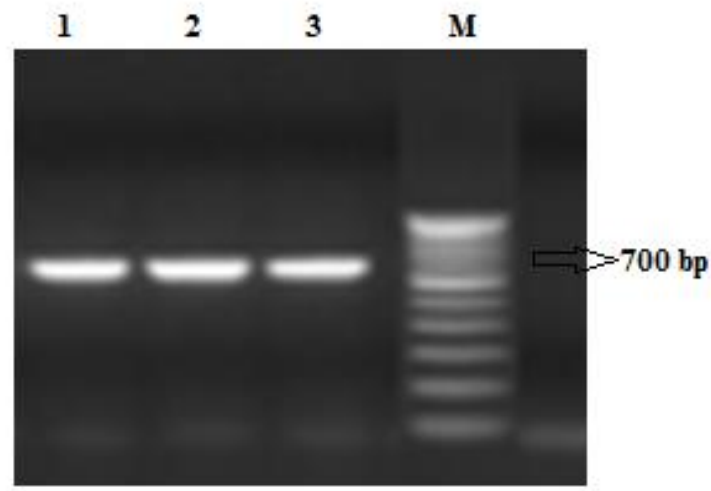

Figure 3 trnK gene sequence amplified by polymerase chain reaction (Lanes: 1 G. sylvestre; 2 - G. elegans; 3 - G. montanum; $\mathrm{M}-100$ bp plus DNA ladder)
The trnK gene sequences of the three Gymnema species were analysed by dideoxy sequencing method and found to have 549, 653, and 573 bp length, respectively. The sequences were short of matK region at $3^{\prime}$ end of the trnK sequence. The trnK sequences of $G$. elegans and $G$. montanum were identical. $G$. sylvestre showed three distinct insertion of adenine nucleotide at 446, 524, and 541 positions at $3^{\prime}$ end. Remaining sequences were identical with $G$. elegans and G. montanum. On Blast analysis, these sequences exhibited $94 \%$ identity (100\% query coverage) with trnK sequences of Mandevilla species as both Mandevilla and Gymnema belong to Gentianales order. These sequences were barcoded and deposited as JX569772, JX569773 and JX569774 in NCBI's nucleotide database for identification.

The phylogenetic tree of trnK sequence showed two major clades one for Gymnema and another Mandevilla. The Gymnema clade showed no distinct sub clade pattern, and no differences in the distance scale among the three species and with $100 \%$ bootstrap support (Figure 4).

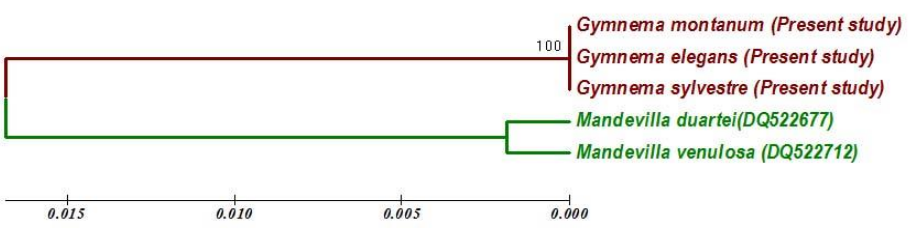

Figure 4 UPGMA Phylogenetic tree from partial trnK gene sequences of Gymnema and Mandevilla species (Bootstrap value (\%) is shown on branch and the scale represents nucleotide substitution per site)

The trnK gene sequence of Gymnema species by RFLP showed no specific restriction pattern after digestion with TaqI enzyme. Each Gymnema species showed three fragments measuring 204, 174, and $168 \mathrm{bp}$. The out group Mandevilla species showed two fragments measuring 331 and 204 bp (Figure 5).

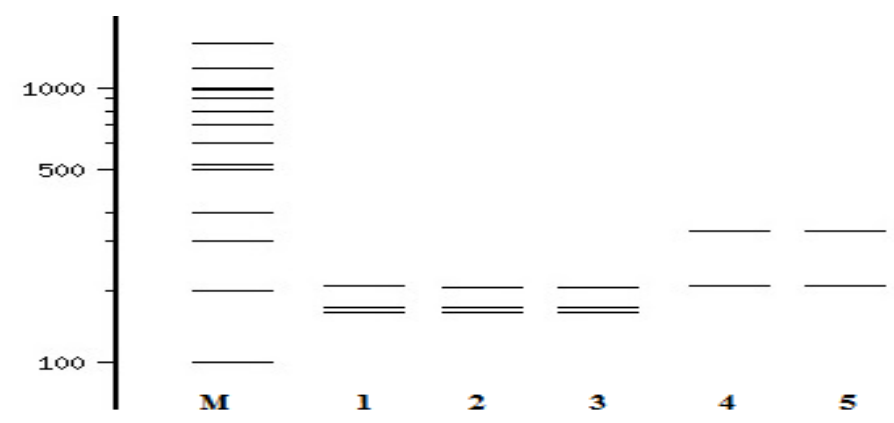

Figure 5 RFLP profiles generated from trnK sequences of three Gymnema and two Mandevilla species after digestion with TaqI restriction enzyme (Lanes: 1 G. sylvestre; 2 - G. elegans; 3- G. montanum; 4- M. duartei; 5- M. venulosa; M 100 bp plus DNA ladder)

\section{DISCUSSION}

The medicinal herbs $G$. sylvestre, $G$. elegans, and $G$. montanum are called by the same vernacular name in Tamilnadu as 'Chakkarakolli'. However, these species exhibits different efficacy and used in different applications (Chattopadhyay, 1998; Wiriyakarun and Yodpetch, 2013). This type of name sharing makes 
confusion on choosing herbal plants and resulting in medication errors that has been reported in many countries (Nadkarni, 1992). According to WHO guidelines on research and evaluation of traditional medicine, first step is assuring quality, safety and efficacy of traditional medicine for correct identification. Hence, the present study attempted to develop species specific markers using RAPD markers and DNA barcode using a trnK gene sequences.

\section{Species identification by RAPD}

RAPD is a quick and cost-effective molecular technique generating anonymous loci that are randomly scattered in the genome (Clark and Lanigan, 1993). This technique is one of the most frequently used molecular methods for taxonomic and systematic analyses of various organisms (Garg et al., 2009). RAPD has been successfully utilized for the identification and genotyping of medicinal plants (Tochika-Komatsu et al., 2001; Um et al., 2001), herbal medicinal components (Shinde et al., 2007), Ornamental plants (De Benedetti et al., 2001) and other varieties of plant species (Temiesak et al., 1993). This technique can able to differentiate the taxa below the species level (Chooet al., 2009), because RAPD analysis performed both coding and non-coding regions (Vanijajiva $\boldsymbol{e}$ al., 2005).The reproducibility of the RAPD markers highly depends upon the quality, quantity of the template DNA and standard PCR conditions (Dinesh $\boldsymbol{e}$ al., 1995). In the present analysis, the concentration of the DNA, concentration of PCR recipes, cycling program, and electrophoretic conditions were consistently maintained for all the 10 RAPD primers and therefore, the markers obtained in the present study are considered to be highly reproducible. These markers can be used for identification of polymorphic status and species identification of Gymnema in future.

The polymorphic percentage of G. sylvestre was found to be $38.32 \%$. This was very low when compared to two previous reports (Smita and Keshavachandran, 2006; Balamurali et al., 2012), where different forms of $G$ sylvestre have been collected from different regions of India and showed $73.2 \%$ and $50 \%$ polymorphism. Relatively low level of genetic polymorphism in this study is due to the small sampling size. Moreover, RAPD primers used in this study revealed notable polymorphism among the Gymnema species. Similarly, considerable polymorphism was found in closely related medicinal herbs Curcuma sp. in Yakushima with C. aeruginosa and C. zedoaria in Java by RAPD markers (Agusta et al., 2007).

The species specific bands obtained in the present study ranged from 354 to 1150 bp. The species specific markers obtained $354 \mathrm{bp}$ in G. sylvestre, $671 \mathrm{bp}$ in $G$. elegans and $923 \mathrm{bp}$ in G. montanum by RP7 primer could be used for species identification in Gymnema species. Similarly unique bands were obtained in medicinal plant Sennaangustifolia species by using different RAPD primers that were clearly discriminate the species (Salim et al., 2011). In addition, geographical specific bands ranged from 130 to $2340 \mathrm{bp}$ were observed in medicinal plants in the previous studies (Smita and Keshavachandran, 2006) Hence, the species specific markers developed in the present study could be used in the identification of these Gymnema species. The UPGMA dendrogram based on Nei's genetic distance revealed the relationship among the three species of Gymnema. The G. sylvestre and G. montanum formed a single cluster indicating that sharing of little RAPD banding pattern between these two species (Figure 2).

\section{Species identification by trnK gene sequence}

The feasibility of chloroplast trnK gene sequence as a DNA barcode of the Gymnema species was concretely tested. The partial trnK sequencing showed advantages of higher efficiency of PCR amplification and sequencing. However, the partial trnK sequencing is insufficient to discriminate the Gymnema species, as the identification efficiency was very low. Multiple sequence alignment showed that $G$. sylvestre had only few numbers of insertion sites in the trnK gene sequences. The sequences were highly conserved and no variation was found. In the BLAST analysis, all the three sequences showed maximum identity with Mandevilla genus. Hence, Mandevilla species was selected as an out group for phylogenetic tree construction and both Mandevilla and Gymnema belonged to the same order Gentianales. Similarly, in the previous studies (Efron et al., 1996) several species have similar sequences with no variable sites in the trnK gene sequences. For example, even though Elettarriopsis and Paramomum were categorized under unique taxonomic position by morphological characters of flowers, they shared similar features and highly conserved with $100 \%$ identity with no variant sites in the trnK sequences (Dhivya et al., 2008).

The present study showed that species identification of Gymnema herb was not possible using phylogenetic analyses constructed from partial trnK sequences. Gymnema and Mandevilla species (out group) formed two separate clades. The Gymnema species formed a single clade suggesting that these species evolved from a common ancestor. And Mandevilla species also showed a single clade. This clade pattern simply reflects the sequence similarity between the species. But in the previous study, this region had enough diversity to discriminate the Curcuma sp. (Agusta et al., 2007). Noticeably, it was found that these trnK gene sequences were used as most useful barcode and provided a universal framework for land plants at and above the generic levels (Ren and Chen, 2010).
Several authors have used the following DNA region for generation of DNA barcode $r b c L, 18$ s rRNA, $p s b A t r n H$, and ITS2 intergenic spacer. Depending upon the plant species and evolutionary rate each region has different efficiency in species identification. Higher efficiency of species discrimination was found in trnK gene than the $r b c L$ gene in Dendrobium species (Asahina and Shinozaki, 2010). It was reported that (Liu et al., 2012) $p s b A-t r n H$ intergenic region is a potential DNA barcoding sequence for identifying the Rhododendron species. Sun et al. (2012) concluded that $t r n \mathrm{~K}$ is a strong, although not perfect, candidate as a DNA barcode for Dioscorea identification. From the analysis of previous findings and our results we conclude that $5^{\prime}$ partial trnK gene sequences of Gymnema species not sufficiently discriminate at species level. Other DNA regions ( $r b c L, p s b A t r n H$, and ITS2 intergenic spacer) should be analyzed to find the best DNA region as a DNA barcode for identification of Gymnema species. PCR-RFLP has been used in several studies and successfully authenticated the medicinal plants such as Mitragyna speciosa, Phyllanthus species, $P$. amarus, $P$. debilis, P. urinaria,Pueraria candollei, Butea superb and Mucuna collettii (Quinteiro et al., 2001; Manissorn et al., 2010; Wiriyakarun and Yodpetch, 2013). In this regard, we attempted to generate a restriction pattern of Gymnema and Mandevilla with in-silico trnK sequence - RFLP analysis. There was no specific restriction pattern observed within the Gymnema or Mandevilla species but different restriction patterns were observed between the Gymnema and Mandevilla species. These restriction patterns will be reference from PCR-RFLP analysis for these species and no need to going for sequencing.

\section{CONCLUSION}

The correct identification of medicinal plants is vital for their conservation and sustainable use, as well as to prevent fake in the marketing of medicinal plants. RAPD and DNA sequence based identification system were used in several plant species (Um et al., 2001; Ren and Chen, 2010). The RAPD primers used in the present study developed species specific markers which could be used for identification of G. sylvestre, G. elegans and G. montanum unambiguously and trnK gene sequences for three species could not be used for identification of species. Present study concluded that the RAPD markers are a candidate for Gymnema species identification than the partial trnK gene sequences.

\section{REFERENCES}

AGUSTA, A., OHASHI, A.E.K., SHIBUYA, A.E.H. 2007. Comparison of Curcuma sp. in Yakushima with C. aeruginosa and C. zedoaria in Java by trnK gene sequence, RAPD pattern and essential oil component. Journal of Natural Medicine, 61(3), 239-243. http://dx.doi.org/10.1007/s11418-006-0131-6

ASAHINA, H., SHINOZAKI, J. 2010. Identification of medicinal Dendrobium species by phylogenetic analyses using matK and rbcL sequences. Journal of Natural Medicine, 64(2), 133-138. http://dx.doi.org/. 10.1007/s11418-009-0379-

BALAMURALI K.R., SUJEETHA, R.R, VIJAYALAXMI, M., ANUGNA, K., DIVYAVANI, N., JAGDEESWARA, R.K. 2012. Molecular characterization of 17 accessions of Gymnema sylvestre R.Br. using RAPD markers. International Journal of Pharma and Biological Sciences, 3(1), 127-135.

CHOO, B.K., MOON, B.C., JI, Y., KIM, B.B., et al. 2009. Development of SCAR markers for the discrimination of three species of medicinal plants, Angelica decursiva (Peucedanumdecursivum), Peucedanum praeruptorum and Anthricus sylvestris, based on the internal transcribed spacer (ITS) sequence and random amplified polymorphic DNA (RAPD). Biological and Pharmaceutical Bulletin, 32, 24-30.

DE BENEDETTI, L., MERCURI, A., BRUNA, S., BURCHI, G., et al. 2001. Genotype identification of ornamental species by RAPD analysis. Acta Horticulture, 546, 391-394.

EFRON, B., HALLORAN, E., HOLMES, S. 1996. Bootstrap confidence levels for phylogenetic trees. Proceedings of National Acadaemy of Science, 13429, 34. CHATTOPADHYAY, R.R. 1998. Possible mechanism of anti hyperglycemic effect of Gymnema sylvestre leaf extract. Gene Pharmacology, 31, 495-496. CLARK, A.G., LANIGAN, C.M.S. 1993. Prospects for estimating nucleotide divergence with RAPDs. Molecular Biology and Evolution, 10(5), 1096-1111. DHIVYA, S., RAJEEV KUMAR, S., RAMALINGAM S., 2008. Phylogenetic analysis of chloroplast matK gene from Zingiberaceae for plant DNA barcoding. Bioinformation, 3(1), 24-27.

DINESH, K.R., CHAN, W.K., LIM, T.M., PHANG, V.P.E. 1995. RAPD markers in fishes: an evaluation of resolution and reproducibility. Asian-Pacific Journal of Molecular Biology and Biotechnology, 3, 112-118.

DOYLE, J.J. 1991. DNA protocols for plants-CTAB total DNA isolation. In: Hewitt GM (ed) Molecular techniques in taxonomy. Springer Berlin, 283-293. FELSENSTEIN, J. 1993. PHYLIP (Phylogeny Inference Package), Version 3.5, Distributed by the author, University of Washington, Seattle.

GARG, R.K., SAIRKAR, P., SILAWAT, N., VIJAY, N., BATAV, N., MEHROTRA, N.N. 2009. Genetic diversity between two populations of Heteropneustes fossilis (Blech) using RAPD profile. International Journal of Zoological Research, 4, 171-177. 
HILLIS, D., MORITZ, C. 1990. An overview of applications of molecular systematics. In: Hillis DM, Moritz C, eds. Molecular systematics. Sunderland, Massachusetts: Sinauer Associates, 502-515.

JOHANNS, E.S., VANDER KOLK, L.E., VAN GEMERT, H.M., SIJBEN A.E., PETERS, P.W., DE VRIES, I. 2002. An epidemic of epileptic seizures after consumption of herbal tea. Nederland Tijdschrift Geneeskunde, 146 (17), 813816.

LEE, S., LEE, T., LEE, B., CHOI, H., YANG, M., IHM, C.G., KIM, M. 2004 Fanconi's syndrome and subsequent progressive renal failure caused by a Chinese herb containing aristolochic acid. Nephrology, 9 (3), 126-129.

LIU, Y., ZHANG, L., LIU, Z., LUO, K., CHEN, S., CHEN, K. 2012. Species identification of Rhododendron (Ericaceae) using the chloroplast deoxyribonucleic acid PsbA-trnH genetic marker. Pharmacognosy Magazine, 8, 29-36. http://dx.doi.org/10.4103/0973-1296.93311

LO, S.H., MO, K.L., WONG, K.S., POON, S.P., CHAN, C.K., LAI, C.K CHAN, A. 2004. Aristolochic acid nephropathy complicating a patient with focal segmental glomerulosclerosis. Nephrology Dialysis Transplantation, 19 (7), 1913-1915.

KIMURA, M. 1980. A simple method of estimating evolutionary rate of base substitutions through comparative studies of nucleotide sequences. Journal of Molecular Evolution, 16 (2), 111-120.

MANISSORN, J., SUKRONG, S., RUANGRUNGSI, N., MIZUKAMI, H. 2010 Molecular phylogenetic analysis of Phyllanthus species in Thai-land and the application of polymerase chain reaction- restriction fragment length polymorphism for Phyllanthus amarus identifi-cation. Biological and Pharmaceutical Bulletin, 33 (10), 1723-1727.

MASILAMANI, G. 1995. Seminar on research in Ayurveda and Siddha (CCRAS, New Delhi)

NADKARNI, A.K. 1992. Indian Materia Medica Vol I In: Gymnema sylvestre Popular Prakashan, Bombay, India, 596-597.

NEI, M. 1978. Estimation of Average hetrozygosity and genetic distance from a small number of individuals. Genetics, 89 (3), 583-590.

NEI, M., LI, W.H. 1979. Mathematical model for studying genetic variation in terms of restriction endonucleases. Proceedings of National Academy of Science 76 (10), 5269-5273

PERSAUD, S.J., AL-MAJED, H., RAMAN, A., JONES, P.M. 1999. Gymnema sylvestre stimulates insulin release in vitro by increased membrane permeability. Journal of Endocrinology, 163 (2), 207-212.

PHUA, D.H., CHAM, G., SEOW, E. 2008. Two instances of Chinese herba medicine poisoning in Singapore. Singapore Medicinal Journal, 49 (5), e131133

QUINTEIRO, J., VIDAL, R., IZQUIERDO, M., SOTELO, C.G., CHAPELA M.J., PEREZ-MARTIN, R.I., REHBEIN, H., HOLD, G.L., RUSSELL, V.J. PRYDE, S.E., ROSA, C., SANTOS, A.T., REY-MENDEZ, M. 2001 Identification of hake species (Merluccius genus) using sequencing and PCRRFLP analysis of mitochondrial DNA control region sequences. Journal of Agricultural Food Chemistry, 49 (11), 5108-5114.

RANA, T.S., SING, K.K, RAO, R.R. 1994. Some interesting reports on indigenous herbal remedies for Diabetes mellitus from India. Fourth International Congress Ethnobiology, (NBRI, Lucknow) 47.

REN, B.Q., CHEN, Z.D. 2010. DNA Barcoding Plant Life. Chinese Bulletin Botany, 45 (1), 1-12

SHIMIZU, K., IINO, A., NAKAJIMA, J., TANAKA, K., NAKAJYO, S. URAKAWA, N., ATSUCHI, M., WADA, T., YAMASHITA, C. 2001 Suppression of glucose absorption by some fractions extracted from Gymnema sylvestre leaves. Journal of Veterinary Medicinal Science, 59 (4), 245-251.

SALIM, K., KHANA, J.M., FAHAD, A.Q., MALIK, Z.A. 2011. Authentication of the medicinal plant Sennaangustifolia by RAPD profiling. Saudi journal of Biological Sciences, 18(3), 287-292.

SHINDE, V.M., DHALWAL, K., MAHADIK, K.R., JOSHI, K.S., et al. 2007. RAPD analysis for determination of components in herbal medicine. Evid. Based Complement Alternative Medicine, 4, 21-23.

SMITA, N., KESHAVACHANDRAN, R. 2006. Molecular diversity in chakkarakolli (Gymnemasylvestre R. Br.) assessed through isozyme and RAPD analysis. Journal of Tropical Agricultural science, 44, 31-36.

SUN, X.Q., ZHU, Y.J., GUO, J.L., PENG, B., BAI, M.M., et al., 2012. DNA Barcoding the Dioscorea in China, a Vital Group in the Evolution of Monocotyledon: Use of matK Gene for Species Discrimination. PLOS ONE, 7(2), e32057. http://dx.doi.org/ 10.1371/journal.pone.0032057

THOMAS, G., SREEJAYAN, DINESH, R.R. 2006. Njavara, the single largest used medicinal rice in the world: Genetic structure, varietal discrimination and phylogenetic affinity. Paper presented at 2nd International Rice Congress on Science, Technology, and Trade for Peace and Prosperity, New Delhi, India, 9 13.

TEMIESAK, P., PONPIM, Y, HARADA, T. 1993. RAPD analysis for varietal identification in Brassica. Kasetsart Journal Natural Science, 27, 37-42.

TOCHIKA-KOMATSU, Y., ASAKA, I., II, I. 2001. A random amplified polymorphic DNA (RAPD) primer to assist the identification of a selected strain, aizu K-111 of Panax ginseng and the sequence amplified. Biological and Pharmaceutical Bulletin, 24, 1210-1213.
UM, J.Y., CHUNG, H.S., KIM, M.S., NA, H.J., et al. 2001. Molecular authentication of Panax ginseng species by RAPD analysis and PCR-RFLP. Biological and Pharmaceutical Bulletin. 24, 872-875.

VANHERWEGHEM, J.L., DEPIERREUX, M., TIELEMANS, C., ABRAMOWICZ, D., DRATWA, M., RICHARD, C., VANDERVELDE, D. VERBEELEN, D., VANHAELEN-FASTRE, R. 1993. Rapidly progressive interstitial renal fibrosis in young women: association with slimming regimen including Chinese herbs. Lancet, 341 (8842), 387-391.

VANIJAJIVA, O., SIRIRUGSA, P., UVACHITTANONT, W. 2005 Confirmation of relationships among Boesenbergia (Zingiberaceae) and related genera by RAPD. Biochemical Systematics and Ecology, 33, 159-170.

WIRIYAKARUN, S., YODPETCH, W. 2013. Discrimination of the Thai rejuvenating herbs Pueraria candollei (White KwaoKhruea), Butea superba (Red KwaoKhruea), and Mucuna collettii (Black KwaoKhruea) using PCR-RFLP. Journal of Natural Medicine, 67(3), 562-570. http://dx.doi.org/10.1007/s11418 012-0716-1

XIE, J.T., WANG, A., MEHENDALE, S., WU, J., AUNG, H.H., DEY, L., QIU, S., YUAN, C.S. 2003. Anti-diabetic effects of Gymnema yunnanense extract Pharmacological Residence, 47 (4), 323-329.

YEH, F.C., YANG, R.C., BOYLE, T. 1999. POPGENE 32-Version 1.31 Population genetics software.

\section{SUPPLEMENTARY PART}

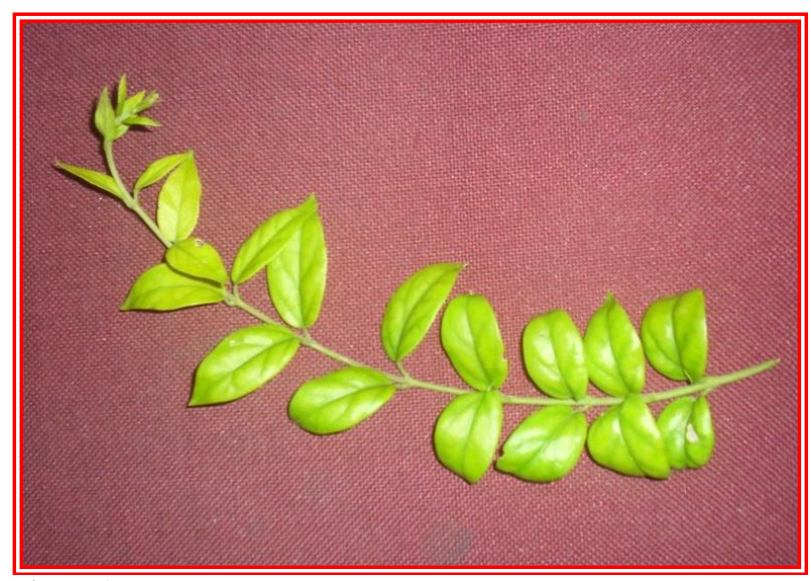

Figure 1 Gymnema sylvestre

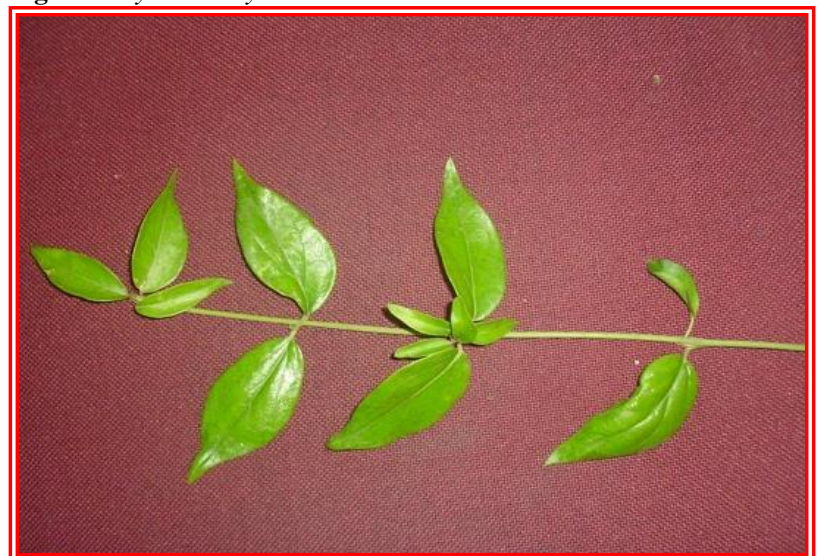

Figure 2 Gymnema elegans

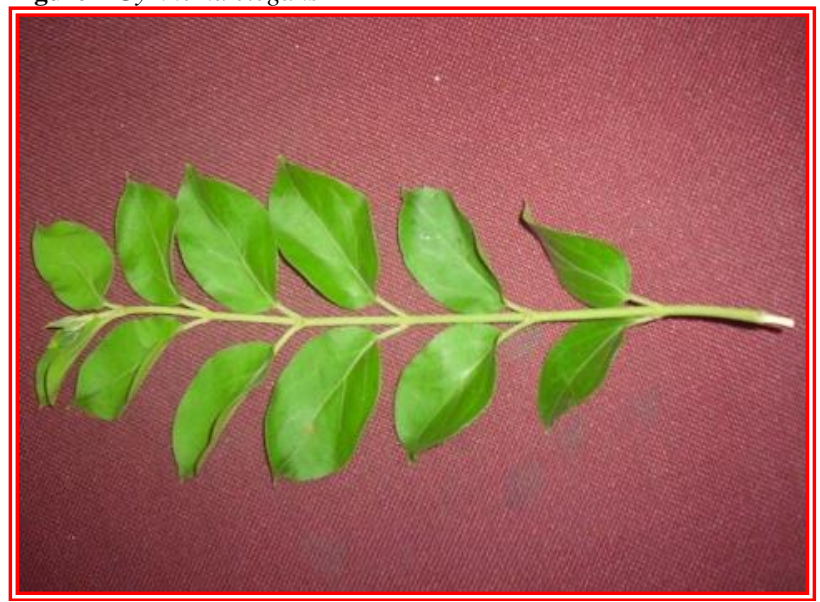

Figure 3 Gymnema 